\title{
Romuald Grzybowski, Polityczne priorytety i elementy codzienności socjali- stycznej szkoły. Wybór studiów poświęconych dziedzictwu edukacyjnemu PRL -u, Wydawnictwo Adam Marszałek, Toruń 2013, ss. 332
}

Romuald Grzybowski jest autorem wielu prac naukowych z zakresu historii edukacji XIX i XX w., szczególnie z obszaru badań naukowych dotyczących roli prasy w procesie wychowania patriotycznego w rodzinach polskich na Pomorzu Nadwiślańskim w okresie zaborów oraz kształcenia nauczycieli w okresie Polski Rzeczpospolitej Ludowej z uwzględnieniem ideologicznych uwarunkowań procesu kształcenia po II wojnie światowej oraz rozwoju nauk pedagogicznych, szczególnie historii wychowania w gdańskim środowisku naukowym.

W recenzowanym zbiorze studiów, treść stanowią zaktualizowane i uzupełnione opracowania będące rezultatem wieloletnich badań naukowych Romualda Grzybowskiego. Dotyczą dziedzictwa edukacyjnego PRL-u, większość z nich została opublikowana również w pracach zbiorowych. Profesor Grzybowski wyjaśnił zakres znaczeniowy pojęć: dziedzictwo kultury, dziedzictwo edukacyjne (które stanowi implikację dziedzictwa kultury), stwierdził, że kategoria pojęciowa: dziedzictwo edukacyjne może służyć cenną pomocą w kształtowaniu tożsamości pedagogów oraz pedagogiki jako dyscypliny naukowej, tym bardziej, że poszczególne składniki dziedzictwa edukacyjnego stanowią implikację kultury pedagogicznej. Należy podkreślić, że Autor wykorzystał w swoim dziele liczne źródła archiwalne i drukowane Ministerstwa Oświaty, Ministerstwa Szkolnictwa Wyższego, Komitetu Centralnego i komitetów wojewódzkich Polskiej Zjednoczonej Partii Robotniczej, Związku Nauczycielstwa Polskiego, również źródła historyczne zakładów kształcących nauczycieli, dokumenty archiwalne Episkopatu Polski. W bibliografii wymienił opracowania naukowe bezpośrednio związane z problematyką dziedzictwa edukacyjnego PRL-u, które wykorzystał w niniejszej pracy.

Książka ma strukturę problemową, składa się z wprowadzenia (które pełni funkcję rozdziału metodologicznego), pięciu części, zakończenia i bibliografii. W pierwszej części: „Powojenne wyzwania społeczno-gospodarcze oraz priorytety PZPR jako czynniki determinujące rozwój edukacji w Polsce w latach 1945-1956" prof. Grzybowski określił uwarunkowania rozwoju edukacji w Polsce po II wojnie światowej, wyjaśnił polityczne, społeczne, gospodarcze czynniki odbudowy oświaty oraz rolę Kursów Przygotowawczych na uczelnie wyższe, cele wychowania komunistycznego, realizowane w socjalistycznych szkołach okresu stalinowskiego, a także priorytetowe cele pedagogiki socjalistycznej.

W części drugiej pt. „Szkoła w systemie społeczno-politycznym PRL-u” Romuald Grzybowski określił miejsce szkoły w programie ideowym i polityce oświatowej PPR, następnie PZPR, przedstawił kryzys ideowy socjalistycznej szkoły w Polskiej Rzeczpospolitej Ludowej w procesie załamania „,pedagogiki stalinowskiej” w październiku 1956. Wyjaśnił na czym polegała walka władz komunistycznych o odzyskanie kontroli nad szkołą polską w latach 1958-1961. Jak wiadomo, w analizowanym okresie historycznym, w państwie komunistycznym szkoła polska oraz zatrudnieni w niej nauczyciele 
mieli realizować założenia ideowe partii, natomiast działalność wychowawczą księży katechetów oceniano negatywnie, przede wszystkim w aspekcie źródła zagrożeń ateizacji szkoły socjalistycznej.

Problematykę pedeutologiczną Autor umieścił w części trzeciej książki: „Ku akademizacji kształcenia nauczycieli szkół podstawowych”, w której zaprezentował proces kształtowania struktury organizacyjnej systemu kształcenia nauczycieli szkół powszechnych (podstawowych) w latach 1945-1948 oraz uzasadnił na czym polegała przebudowa ideowo-programowa zakładów kształcących nauczycieli w latach 1948-1956. Romuald Grzybowski ustalił, że proces akademizacji systemu kształcenia nauczycieli szkół podstawowych (powszechnych) był żmudny i został zwieńczony w 1973 r. decyzją władz o kształceniu nauczycieli na poziomie wyższym.

Problematyka dotycząca nauczycieli została również omówiona w czwartej części recenzowanej publikacji, którą Romuald Grzybowski zatytułował: „Nauczyciele socjalistycznej szkoły z lat PRL-u”. Autor opisał trudną, ze względów politycznych, sytuację nauczycieli pracujących w szkołach socjalistycznych, od których oczekiwano właściwej postawy ideowej, począwszy od procesu doboru i selekcji kandydatów do zawodu nauczycielskiego, następnie w procesie ich kształcenia i doskonalenia zawodowego, gdy formułowano wymagania polityczne, prowadzono szkolenia ideologiczne nauczycieli. Autor recenzowanej książki wyjaśnił również propagandowy aspekt czasopism pedagogicznych w procesie ideologicznego szkolenia nauczycieli w latach PRL-u, w zakresie promowania socjalistycznego modelu osobowego nauczyciela, działającego w warunkach państwa totalitarnego.

W piątej części recenzowanej publikacji: „Uczeń - rodzina - szkoła. Próby współdziałania i elementy oporu przeciwko założeniom realizowanego przez szkołę wychowania socjalistycznego" wyjaśnił trudną (niezrównoważoną, bezduszną) sytuację dziecka - ucznia oraz jego rodziców w relacjach ze szkołą w socjalistycznym modelu wychowania komunistycznego w okresie Polski Rzeczpospolitej Ludowej, których - co należy szczególnie podkreślić - uprzedmiotowiono w strukturach państwa totalitarnego. Profesor Romuald Grzybowski wyjaśnia, że w przedmiotowym okresie historycznym dziecko było traktowane jako „dobro państwowe” w instytucjach wychowania bezpośredniego i pośredniego. Przypomniał także tragiczny los dzieci rodziców represjonowanych, zniewolonych, aresztowanych ze względów politycznych, dzieci poczętych w warunkach obozowych, urodzonych przez kobiety uwięzione w łagrach, omówił socjalistyczną (zakłamaną) ,pedagogizację” ich rodziców.

Autor w wyborze studiów poświęconych dziedzictwu edukacyjnemu Polski Rzeczpospolitej Ludowej zrekonstruował okoliczności i warunki odrodzenia się ruchu harcerskiego w Polsce po 1956 r., polityczne i ideologiczne konteksty odbudowy programowej harcerstwa, wprowadzenia zmian (1957) w rocie Przyrzeczenia Harcerskiego, w której opuszczono „służbę Bogu” i zamiast: „nieść chętnie pomoc bliźniemu” wprowadzono: „nieść chętną pomoc każdemu człowiekowi”, następnie dopisano: „walkę w służbie prawdy i sprawiedliwości społecznej”. Romuald Grzybowski zaznaczył, że władzom partyjnym w okresie PRL-u zależało na wkomponowaniu ZHP w proces wychowania komunistycznego i z tego powodu włączono harcerstwo w świecką strukturę systemu szkolnego. 
W zakończeniu (recenzowanej publikacji) pt. „Zamiast zakończenia... czyli o warunkach i niektórych rezultatach socjalizacji przebiegającej w warunkach konfliktu ideowo-politycznego w latach PRL-u” Romuald Grzybowski sformułował kilka wniosków z przeprowadzonych badań naukowych; dotyczą one głównie efektów procesu socjalizacji Polaków w państwie totalitarnym. Należy dodać, że książka Profesora Romualda Grzybowskiego jest bardzo dobrze udokumentowana, a oprócz przypisów dokumentacyjnych implikuje również przypisy dopowiadające, polemiczne, słownikowe. Z pewnością może służyć również cenną pomocą dydaktyczną w lepszym zrozumieniu warunków kształtowania wszystkich kategorii postaw w społeczeństwie polskim w okresie PRL-u, zwłaszcza ideowych, szeroko pojętego dziedzictwa edukacyjnego Polskiej Rzeczpospolitej Ludowej. Tym bardziej, że historia Polski z lat 1945-1989 jest słabo znana wśród studentów, co ujawniają badania naukowe, które Autor przytacza we wprowadzeniu do niniejszej publikacji.

Edyta Wolter

\section{Piotr Gołdyn, Stawomir Czerwiński (1885-1931). Minister oświaty, przyjaciel Kalisza, Kalisz 2013, ss. 88}

Praca zatytułowana Stawomir Czerwiński (1885-1931). Minister oświaty, przyjaciel Kalisza ukazała się jako szósty tom w serii „Kaliszanie” nakładem Kaliskiego Towarzystwa Przyjaciół Nauk. Autorem tej publikacji jest Piotr Gołdyn ${ }^{1}$. Seria ta kontynuuje prezentację zasłużonych mieszkańców tego miasta. Nie tylko tych rodowitych, lecz także „kaliszan z wyboru”, przybyłych w związku z edukacją lub pracą, a których dokonania są także warte przypomnienia.

Jako ważny powód popularyzacji życia i działalności S. Czerwińskiego - wybitnego pedagoga, późniejszego Ministra Wyznań Religijnych i Oświecenia Publicznego w II Rzeczypospolitej Polskiej, twórcy Instytutu Nauczycielskiego w Warszawie - Autor podaje lukę w panteonie znaczących postaci związanych z II RP. W opinii Autora może to być spowodowane przedwczesną śmiercią ministra, odejściem Józefa Piłsudskiego od modelu wychowania państwowego, rządami komunistycznmi oraz niechęcią do sanacji.

1 Piotr Gołdyn jest doktorem nauk humanistycznych, historykiem oraz regionalistą. Studiował na Papieskim Wydziale Teologicznym w Warszawie. W roku 2002 obronił rozprawę doktorską na Uniwersytecie Zielonogórskim. Jest także członkiem zarządu Kaliskiego Towarzystwa Przyjaciół Nauk oraz członkiem Towarzystwa Historii Edukacji. Współpracuje ze Związkiem Polaków w Rumunii. Jest autorem i redaktorem kilkunastu książek oraz ponad dwustu artykułów naukowych, popularnonaukowych i popularnych. M.in.: Symbolika religijna i kościelna $w$ herbach miast polskich do końca XX wieku, Warszawa 2008; Z pól do wolności. Szkic do dziejów opozycji wiejskiej na ziemi konińskiej (1980-1989), Konin 2009; Trud i chwała strażaka. Dzieje Ochotniczej Straży Pożarnej w Lądku w latach 1908-2008, t. I, Lądek 2009; Protestantyzm w Polsce na przestrzeni wieków, Poznań 2009; II wojna światowa w Wielkopolsce Wschodniej. Wybrane aspekty, Konin 2010; Religia w procesie resocjalizacji, Konin 2010; Dzieje Sompolna, t. I, Wiek XX, Sompolno 2011; Diamentowa książnica. Sześćdziesiąt lat Publicznej Biblioteki Pedagogicznej w Koninie, Konin 2012. 